\title{
Wpływ energii liniowej spawania wiązką laserową na mikrostrukturę i wybrane właściwości połączeń ze stali AHSS na przykładzie CPW 800
}

\author{
Effect of laser welding linear energy \\ on microstructure and selected properties \\ of AHSS steel joints of the CPW 800
}

\section{Streszczenie}

Praca dotyczy problematyki spawania laserowego stali typu CPW 800 z mikrododatkami Ti i Nb. Próby spawania laserowego blach walcowanych termomechanicznie prowadzono techniką głębokiego przetopienia z wykorzystaniem lasera na ciele stałym. Przeprowadzono próby przy różnej energii liniowej procesu, a następnie wykonano badania metalograficzne makroskopowe i mikroskopowe oraz oceniono twardość materiału rodzimego, strefy wpływu ciepła i spoiny. Określono wpływ energii liniowej spawania na szerokość spoiny. Twardość spoiny wynosi około 400 HV1 niezależnie od energii liniowej spawania, a dominującym składnikiem strukturalnym złącza jest martenzyt niskowęglowy. Przedstawiono wyniki badania wytrzymałości na rozciąganie połączeń spawanych.

Słowa kluczowe: spawanie laserowe, stal AHSS
Abstract

This study discusses issues related to laser welding of the CPW 800 steel with $\mathrm{Ti}$ and $\mathrm{Nb}$ microadditions. The tests of laser welding of thermomechanically rolled sheet samples were carried out using keyhole welding and a solid-state laser. The tests performed for the various values of linear energy were followed by macro- and microscopic metallographic investigations as well as by the hardness measurements of base metal, heat-affected zone and fusion weld. The effect of welding linear energy on a weld width has been determined. The weld hardness is approximately $400 \mathrm{HV} 1$ independent on the welding linear energy applied. Low-carbon martensite is a dominant microstructural constituent of the joint. Results of tensile strength test of welded joint were presented.

Keywords: laser welding, Advanced High-Strength Steel

\section{Wstęp}

Zapotrzebowanie przemysłu motoryzacyjnego na materiały o korzystnym połączeniu własności mechanicznych i technologicznych determinuje opracowywanie nowych stopów wysokowytrzymałych, posiadających dużą plastyczność i odkształcalność technologiczną.

W ostatniej dekadzie największy postęp technologiczny w motoryzacji można odnotować w zakresie opracowania i wytwarzania nowoczesnych stali wysokowytrzymałych z grupy AHSS (Advanced HighStrength Steels), które umożliwiają redukcję masy

dr inż. Maciej Różański - Instytut Spawalnictwa, dr hab. inż. Adam Grajcar, prof. Pol. Śl. - Politechnika Śląska, Instytut Materiałów Inżynierskich i Biomedycznych, dr inż. Sebastian Stano - Instytut Spawalnictwa. 
struktury nośnej samochodu przy jednoczesnym zwiększeniu bezpieczeństwa biernego [1 $\div 6]$. Charakterystyczną cechą stali AHSS jest ich wielofazowa mikrostruktura, zapewniająca korzystne połączenie między wytrzymałością i plastycznością. Do grupy tych stali zalicza się stale typu Dual Phase (DP), Transformation Induced Plasticity (TRIP) oraz Complex Phase (CP). Ograniczenie masy samochodu jest możliwe dzięki kompleksowemu podejściu obejmującemu zastępowanie klasycznych stali głębokotłocznych przez wysokowytrzymałe stale AHSS, stosowanie nowoczesnych metod kształtowania blach oraz stosowanie wysokowydajnych procesów ich łączenia.

Zapewnienie odpowiedniej spawalności stali, a także odkształcalności blach stalowych jest zawsze kompromisem pomiędzy własnościami mechanicznymi i technologicznymi. Skład chemiczny stali typu CP oraz ich własności mechaniczne zapewnione na drodze obróbki cieplnej lub cieplno-plastycznej lokują je w górnym zakresie wytrzymałości i umiarkowanym zakresie plastyczności uzyskiwanym przez stale AHSS $[2 \div 5,7]$. Cechą charakterystyczną tych stali - bazujących na osnowie bainitycznej - jest mała różnica twardości pomiędzy poszczególnymi składnikami strukturalnymi. Cecha ta powoduje, że stale Complex Phase charakteryzują się dobrą tzw. „lokalną ciągliwością", szczególnie pożądaną przy zaginaniu obrzeży blach i wywijaniu kołnierzy $[8,9]$. Z tego względu znajdują one zastosowanie na elementy o skomplikowanym kształcie stanowiące wzmocnienia boczne drzwi, elementy siedzeń i paneli podłogowych $[5,9]$.

Obecnie dominującą technologią łączenia elementów karoserii samochodowych jest zgrzewanie rezystancyjne, ze względu na dużą wydajność i niezawodność procesu $[2 \div 4,10,11]$. Coraz większe znaczenie zyskuje spawanie laserowe, które można stosować w różnych odmianach, jak $\mathrm{np}$. spawanie laserowe z wiązką zogniskowaną w dwóch punktach (bifocal welding) [4,12]. Spośród stali wielofazowych dotychczas najwięcej uwagi poświęcono spawalności stali typu DP [13:15]. Generalnie w zakresie wytrzymałości do $800 \mathrm{MPa}$ ich spawalność nie nastręcza większych trudności, głównie ze względu na ograniczone do 0,1\% stężenie węgla. Znacznie większe problemy występują w przypadku łączenia stali TRIP, które zawierają podwyższone stężenie węgla $(0,2-0,3 \%)$. Towarzyszące dużej szybkości chłodzenia tworzenie się struktur martenzytycznych prowadzi do twardości złącza w zakresie od 420 do 550 HV $[5,16,17]$. W tym przypadku zalecane jest stosowanie dodatkowego impulsu cieplnego mającego na celu odpuszczenie mikro- struktury $[4,18]$. Dodatkowym problemem jest duża podatność stali TRIP do tworzenia licznych wtrąceń niemetalicznych w strefie przetopionej $[19,20]$.

Zagadnienie spawalności stali typu CP dotychczas jest rzadko podejmowane. Stale typu CP zawierają podobne stężenie $C$ do stali dwufazowych. Należy się spodziewać, że ich spawalność powinna być relatywnie dobra. $Z$ drugiej strony zawierają podwyższone stężenie $\mathrm{Cr}$, Mo, Si i/lub Al, zwiększających skłonność stali do podhartowania. Elementem wyróżniającym te stale są mikrododatki Nb i Ti wprowadzone w celu rozdrobnienia ziarna.

W tym kontekście należy wykorzystać doświadczenia łączenia stali HSLA wytwarzanymi przez walcowanie termomechaniczne $[21 \div 23]$. W trakcie spawania może dochodzić do zaburzenia dyspersyjnego rozmieszczenia węglikoazotków w strukturze złącza, co może powodować w niektórych warunkach zwiększenie skłonności złączy do pękania [23].

\section{Materiał do badań}

Do badań wpływu energii liniowej spawania laserowego na mikrostrukturę i właściwości połączeń ze stali CPW 800 użyto blach o grubości $2,5 \mathrm{~mm}$. Z arkuszy blach o wymiarach $1000 \times 1500 \mathrm{~mm}$ wycięto laserowo próbki do badań laboratoryjnych o wymiarach $150 \times 300 \mathrm{~mm}$. Z krawędzi ciętych laserowo przed procesem spawania usunięto mechanicznie warstwę tlenkową a powierzchnię blach na szerokości $50 \mathrm{~mm}$ od krawędzi spawanej odtłuszczono acetonem. Skład chemiczny stali CPW 800 zgodnie $z$ atestem wytwórcy, firmy Thyssen Krupp Stahl AG, przedstawiono w tablicy I. Jest to produkowana przemysłowo stal walcowana na gorąco i poddana kontrolowanemu chłodzeniu. Stal zawiera ograniczone stężenie węgla (ok. 0,08\%) oraz podwyższoną zawartość Mn, Si i Cr zwiększających jej hartowność. Dodatkowo zwiększone stężenie krzemu i aluminium ma na celu ograniczenie procesu wydzieleniowego węglików w bainicie $[1,2,9]$. Mikrododatki Ti i Nb (tabl. I) wprowadzono w celu rozdrobnienia mikrostruktury i utwardzania wydzieleniowego stali $[9,23]$.

\section{Stanowisko do badań oraz wykonanie połączeń próbnych}

Próby spawania laserowego stali prowadzono techniką głębokiego przetopienia („keyhole welding”)

Tablica I. Skład chemiczny blachy stalowej w gat. CPW800, \% wag Table I. Chemical composition of the CPW800 steel sheet, wt.\%

\begin{tabular}{|c|c|c|c|c|c|c|c|c|c|c|}
\hline $\mathrm{C}$ & $\mathrm{Mn}$ & $\mathrm{Si}$ & $\mathrm{Cr}$ & $\mathrm{S}$ & $\mathrm{P}$ & $\mathrm{Ti}$ & $\mathrm{N}$ & $\mathrm{Al}$ & $\mathrm{Mo}$ & $\mathrm{C}$ \\
\hline 0,08 & 1,72 & 0,56 & 0,34 & 0,003 & 0,010 & 0,125 & 0,002 & 0,29 & 0,016 & 0,46 \\
\hline
\end{tabular}


z wykorzystaniem lasera na ciele stałym, zintegrowanego ze zrobotyzowanym systemem do obróbki laserowej, zainstalowanym w Instytucie Spawalnictwa w Gliwicach. Powyższe stanowisko laboratoryjne spełnia wymagania stawiane współczesnym, najnowszym stanowiskom przemysłowym i jest wyposażone w:

- Laser TruDisk 12002 - laser na ciele stałym typu Yb:YAG firmy Trumpf o maksymalnej mocy $12 \mathrm{~kW}$ i jakości wiązki laserowej określanej parametrem $\mathrm{BPP} \leq 8 \mathrm{~mm} \cdot \mathrm{mrad}$,

- głowicę CFO firmy Trumpf (rys. 1) połączoną ze źródłem laserowym światłowodem o średnicy $300 \mu \mathrm{m}$ i soczewką skupiającą o długości ogniskowej fog $=300 \mathrm{~mm}$. Średnica ogniska wiązki laserowej wynosiła $450 \mu \mathrm{m}$.

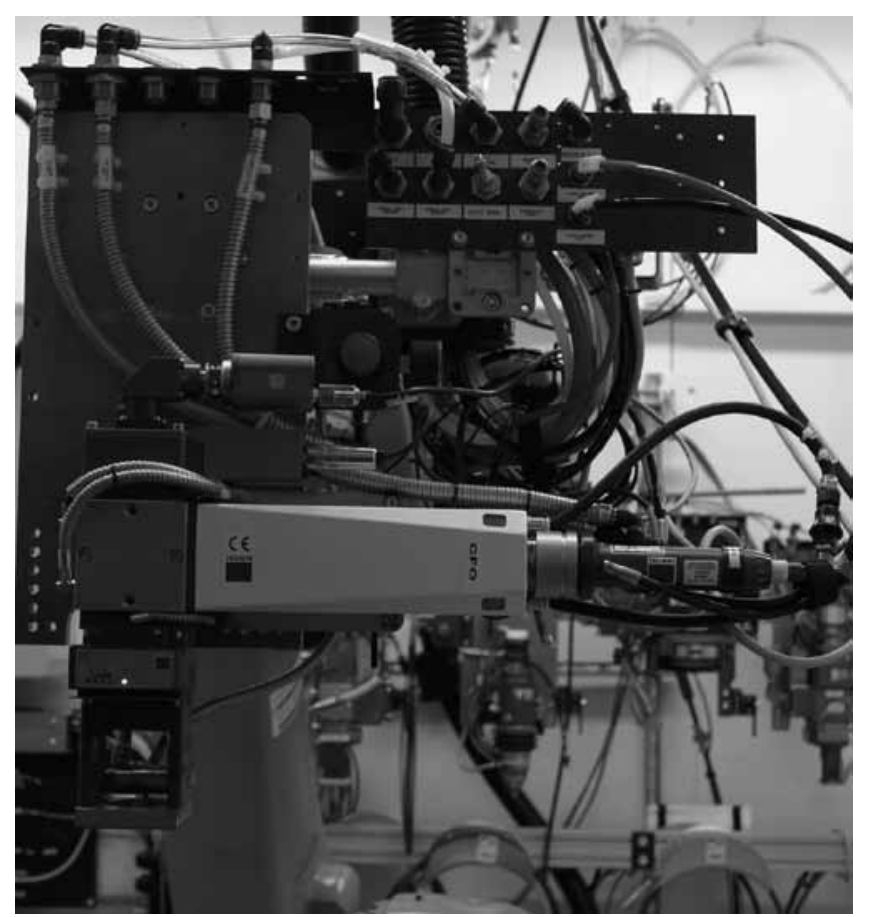

Rys. 1. Głowica CFO do spawania wiązką laserową techniką z głębokim przetopieniem

Fig. 1. The CFO head for laser beam keyhole welding

W celu zapewnienia dokładnego pozycjonowania wiązki laserowej wzdłuż linii styku spawanych blach, odcinki próbne zamocowano za pomocą systemu docisków mimośrodowych do stołu będącego integralną częścią stanowiska. W celu dobrania parametrów spawania, zapewniających uzyskanie prawidłowego kształtu spoiny oraz przetapiania na wskroś, przeprowadzono próbne przetapianie blach ze stali niestopowej o grubości odpowiadającej grubości badanych materiałów.

W celu określenia wpływu parametrów spawania wiązką laserową na właściwości mechaniczne oraz mikrostrukturę połączeń spawanych wykonano złącza próbne doczołowe, stosując różne warianty parametrów procesu. Dobór parametrów oparto na doświadczeniu własnym oraz wynikach wstępnych prób przetapiania blach o grubości $2,5 \mathrm{~mm}$. Wytypowano
5 wariantów parametrów umożliwiających uzyskanie poprawnych jakościowo złączy, tj. z przetopieniem na całej grubości materiału podstawowego, brakiem rozprysku, przepaleń, podtopień, itp.

Blachy ze stali CPW 800 mocowano na stole montażowym z zaciskami, gwarantującymi precyzyjne pozycjonowanie złącza wzdłuż zadanej trajektorii wiązki laserowej. Krawędzie złącza przygotowano na I i zamocowano bez odstępu, a spawanie prowadzono w atmosferze powietrza. Wykonano 5 złączy próbnych przy wytypowanych zestawach parametrów spawania (tabl. II).

Tablica II. Parametry spawania laserowego blach ze stali CPW 800 o grubości $2,5 \mathrm{~mm}$

Table II. Parameters of laser welding of 2,5 mm thick CPW 800 steel sheets

\begin{tabular}{|c|c|c|c|c|c|}
\hline Nr próbki & 11 & 12 & 13 & 14 & 15 \\
\hline $\begin{array}{c}\text { Moc wiązki, } \\
\mathrm{kW}\end{array}$ & 2 & 3 & 4 & 4 & 5 \\
\hline $\begin{array}{c}\text { Prędkość } \\
\text { spawania, } \\
\mathrm{mm} / \mathrm{s}\end{array}$ & 33 & 60 & 83 & 100 & 130 \\
\hline $\begin{array}{c}\text { Energia } \\
\text { liniowa, } \\
\mathrm{kJ} / \mathrm{mm}\end{array}$ & 0,060 & 0,050 & 0,048 & 0,040 & 0,037 \\
\hline
\end{tabular}

W celu przygotowania próbek do badań metalograficznych i pomiaru twardości spawane złącza przecięto w płaszczyźnie prostopadłej do osi spoiny, w środku długości przetopionej dla każdego wariantu. Badania metalograficzne wykonano dla 5 wariantów spawania, a szczegółowej analizie mikrostrukturalnej poddano złącze wykonane przy energii liniowej spawania $0,05 \mathrm{~kJ} / \mathrm{mm}$. Przygotowanie polegało na zainkludowaniu próbek w żywicy epoksydowej, szlifowaniu na papierach o numeracji kolejno: 80, 320, 1000 i 2500, a następnie polerowaniu na płótnach polerskich z dodatkiem zawiesiny polerskiej, kolejno diamentowej i korundowej o wielkości ziarna odpowiednio 3 i 0,05 $\mu \mathrm{m}$. Mikrostrukturę próbki ujawniono poprzez jej trawienie w $3 \%$ nitalu a następnie w wodnym roztworze pirosiarczanu potasu. Celem dodatkowego trawienia w pirosiarczanie potasu było ujawnienie austenitu szczątkowego.

\section{Wyniki badań}

\section{Badania metalograficzne makroskopowe}

Badania metalograficzne makroskopowe prowadzono przy użyciu mikroskopu świetlnego typu MeF4 firmy Leica przy powiększeniu 25x. Badania przeprowadzono dla próbek wykonanych z zastosowaniem wszystkich wytypowanych wariantów parametrów.

W przypadku każdego badanego złącza dokonano 
pomiaru szerokości przetopienia oraz strefy wpływu ciepła (SWC). Pomiaru szerokości poszczególnych obszarów dokonano w połowie grubości blachy (rys. 2a). Wyniki pomiaru zmian szerokości przetopienia oraz strefy wpływu ciepła w funkcji energii liniowej procesu przedstawiono na rysunku $2 \mathrm{~b}$.
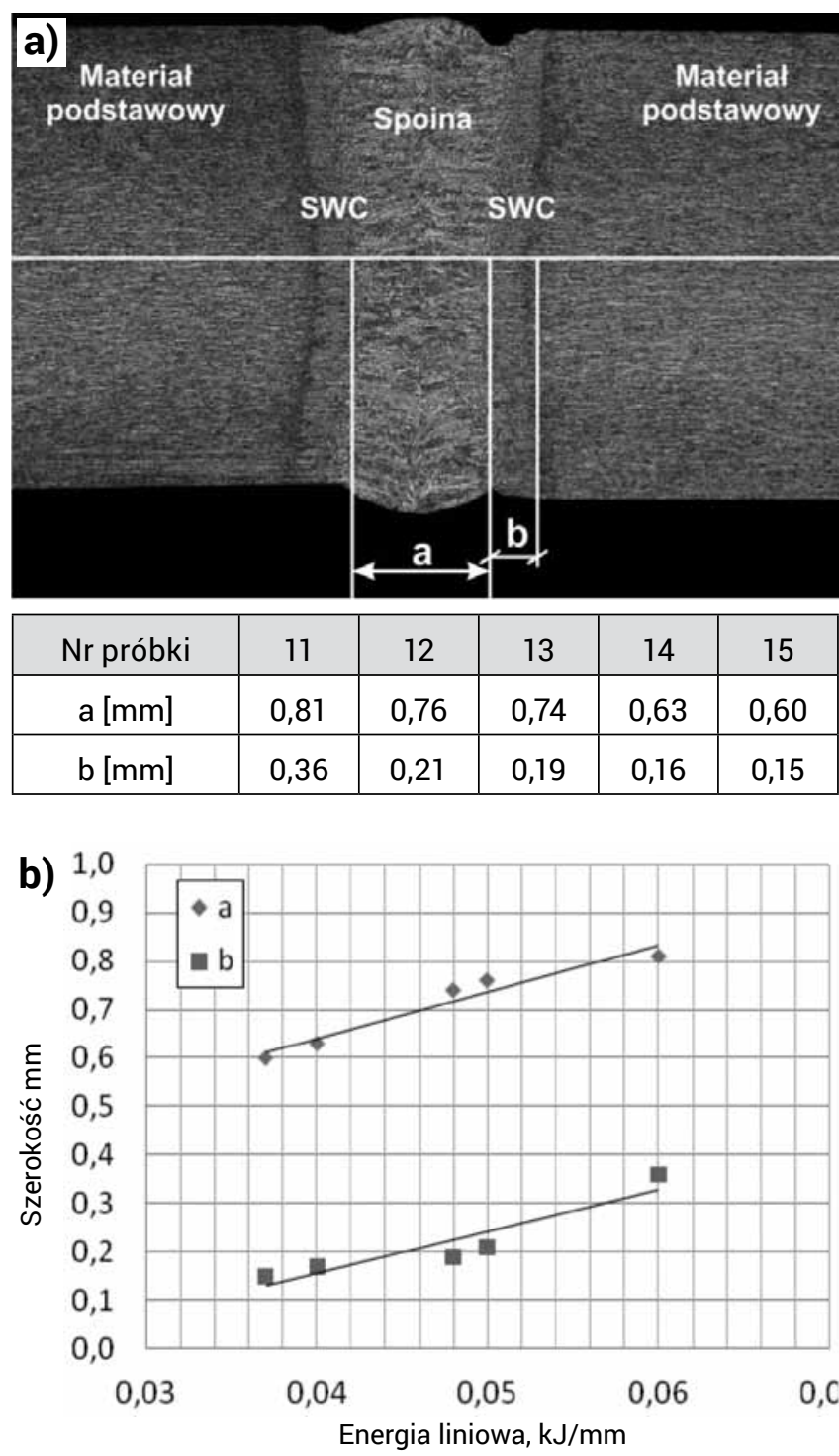

Rys. 2. Miejsce wykonania pomiaru szerokości spoiny oraz strefy wpływu ciepła (a) oraz wyniki pomiaru dla połączeń wykonanych z różną energią liniową (b)

Fig. 2. Area of measurements of the fusion weld and heat affected zone widths (a) and results for the joints welded at a different linear energy

Otrzymane wyniki wskazują, że wraz ze zwiększeniem energii liniowej spawania zwiększa się zarówno szerokość spoiny (a - rys. 2b) jak i strefy wpływu ciepła (b - rys. 2b). Spoina wraz ze strefą wpływu ciepła wykonana przy najmniejszej energii liniowej $(0,037 \mathrm{~kJ} / \mathrm{mm})$ wykazuje najmniejszą szerokość - odpowiednio 0,60 i $0,15 \mathrm{~mm}$ (rys. 2b). Największą szerokość spoiny oraz strefy wpływu ciepła - odpowiednio 0,81 i $0,36 \mathrm{~mm}$ - wykazuje złącze wykonane przy energii liniowej $0,060 \mathrm{~kJ} / \mathrm{mm}$.
Na rysunku 3 przedstawiono makrostruktury połączeń wykonanych z różną energią liniową. Wykonane złącza cechują się dobrą jakością, tj. zaobserwowane niezgodności spawalnicze (np. podtopienia) mieszczą się w poziomie jakości B wg PN-EN ISO 13919-1.
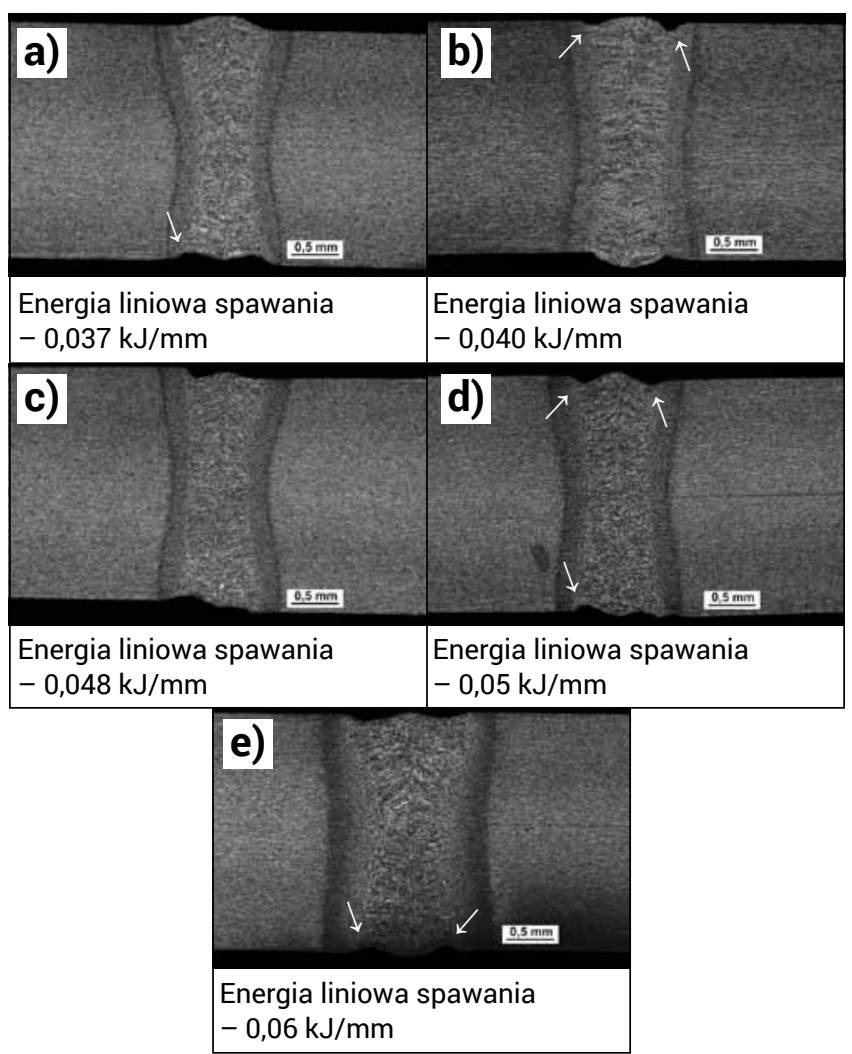

Rys. 3. Makrostruktura złączy ze stali CPW 800 spawanych laserowo z różną energią liniową: $0,037 \mathrm{~kJ} / \mathrm{mm}$ (a), 0,040 kJ/mm (b), 0,048 $\mathrm{kJ} / \mathrm{mm}$ (c), 0,05 kJ/mm (d) oraz 0,06 kJ/mm (e)

Fig. 3. Macrostructure of the CPW 800 steel joints laser-welded at a different linear energy: 0,037 kJ/mm (a), 0,040 kJ/mm (b), 0,048 $\mathrm{kJ} / \mathrm{mm}$ (c), 0,05 kJ/mm (d) and 0,06 kJ/mm (e)

Makrostruktury charakteryzuje typowe, kolumnowe ułożenie kryształów, równolegle do kierunku najszybszego odprowadzania ciepła, $\mathrm{tj}$. prostopadle do osi wzdłużnej spoiny.

\section{Mikrostruktura spoiny oraz strefy wpływu ciepła złączy spawanych}

Badaniom mikrostruktury poddano materiał podstawowy oraz złącze spawane, tj. spoinę $i$ strefę wpływu ciepła w trzech miejscach: w obszarze bezpośrednio przylegającym do spoiny, w połowie szerokości SWC oraz od strony materiału podstawowego. Mikrostrukturę materiału podstawowego po walcowaniu termomechanicznym stanowi osnowa bainityczno-ferrytyczna (B-F), w której rozmieszone są wyspy martenzytyczno-austenityczne (M-A) o zróżnicowanej wielkości (rys. 4). Największe wyspy M-A mogą być przyczyną zaniżenia udarności złącza [24]. 
Zidentyfikowano także drobne ziarna austenitu szczątkowego. Ich udział jest niewielki i może mieścić się w przedziale 3-5\%, jak podaje wytwórca stali. Mikrostruktura charakteryzuje się dużym stopniem rozdrobnienia i uprzywilejowanym ułożeniem ziarn względem kierunku walcowania.

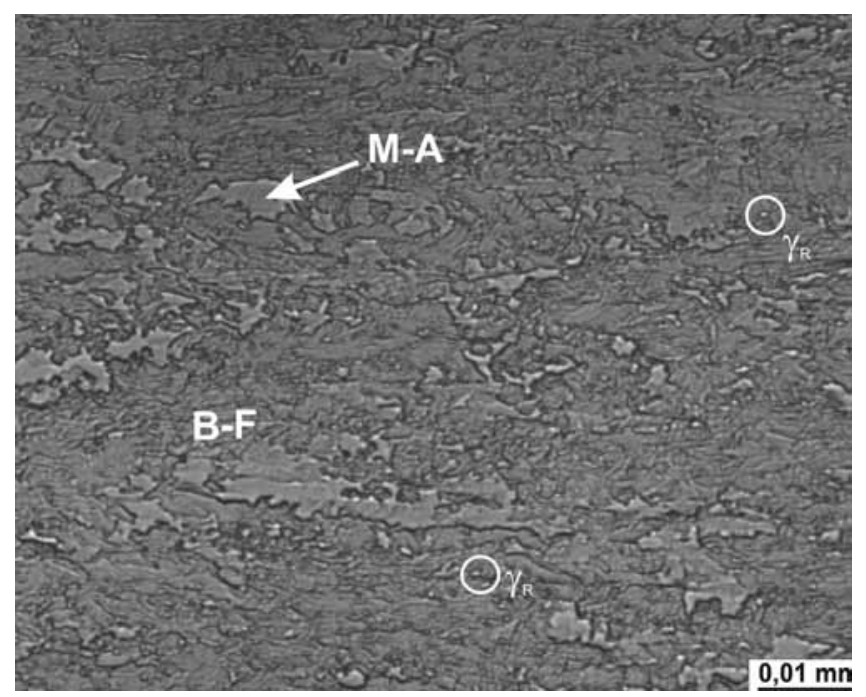

Rys. 4. Mikrostruktura stali CPW800 z widocznymi wyspami martenzytyczno-austenitycznymi M-A i austenitem szczątkowym $y R$ w osnowie bainityczno-ferrytycznej $(B+F)$

Fig. 4. Microstructure of the CPW800 steel with martensiticaustenitic islands $M-A$ and retained austenite $\gamma R$ located in the bainitic-ferritic matrix $(B+F)$

Do badań metalograficznych mikroskopowych wytypowano złącze wykonane przy pośredniej energii liniowej spawania wynoszącej $0,050 \mathrm{~kJ} / \mathrm{mm}$. Wyniki badań mikrostrukturalnych przedstawiono na rysunku 5. Mikrostrukturę złącza przetopionego stanowi martenzyt listwowy, przy czym wielkość listew jest największa w osi przetopienia (rys. 5b) i zmniejsza się w kierunku strefy wpływu ciepła (rys. 5c, d). Strukturę strefy wpływu ciepła $w$ pobliżu linii wtopienia stanowi martenzyt drobnolistwowy (rys. 5e). Strefa wpływu ciepła od strony materiału podstawowego wykazuje mikrostrukturę w postaci mieszaniny martenzytu z bainitem. Przejście między strefą wpływu ciepła a materiałem rodzimym charakteryzuje drobnoziarnista mieszanina składająca się z bainitu, ferrytu i austenitu szczątkowego (rys. 5f). Zwiększony udział drobnych ziarn austenitu szczątkowego w strefie przejściowej jest wynikiem częściowego wzbogacenia austenitu w węgiel w zakresie temperatur międzykrytycznych (pomiędzy Ac1 a Ac3). Podobną strefę o zwiększonym udziale fazy $\gamma$ często obserwuje się w stalach typu TRIP, zgodnie $z$ danymi literaturowymi $[16,17,19]$. Potwierdzenie obecności austenitu szczątkowego oraz roli dyspersyjnych wydzieleń węglikoazotków zawierających Ti i Nb w kształtowaniu struktury drobnoziarnistej wymaga jednak dalszych badań z wykorzystaniem skaningowej i transmisyjnej mikroskopii elektronowej, a także badań składu fazowego (badania dyfrakcyjne).

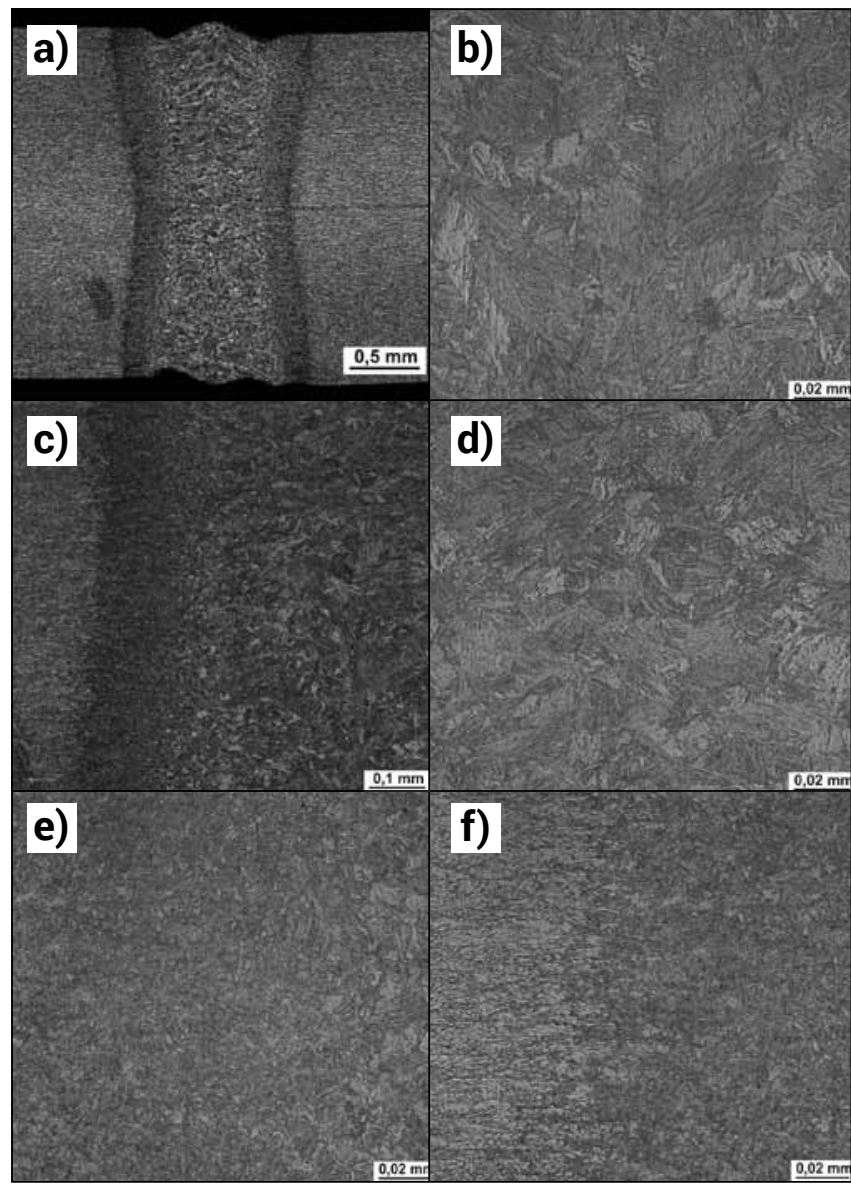

Rys. 5. Makrostruktura (a) i mikrostruktura złącza wykonanego $\mathrm{z}$ energią liniową $0,05 \mathrm{~kJ} / \mathrm{mm}$ : mikrostruktura spoiny (b), strefy wpływu ciepła (c) oraz poszczególne obszary SWC (d, e, f)

Fig. 5. Macrostructure (a) and microstructure of the joint made at a linear energy of $0,05 \mathrm{~kJ} / \mathrm{mm}$ : microstructures of the fusion weld (b), heat affected zone (c) and particular HAZ areas (d, e, f)

\section{Pomiar twardości na przekroju poprzecznym złączy spawanych}

Pomiar twardości na przekroju poprzecznym złączy spawanych przeprowadzono za pomocą urządzenia KB50BVZ-FA firmy KB Prüftechnik stosując obciążenie wgłębnika 9,81 N (HV1). Pomiaru dokonano od osi spoiny w obu kierunkach, ustalając odległość pomiędzy punktami pomiarowymi co $0,2 \mathrm{~mm}$. Linia pomiaru przebiegała w środku grubości spoiny. Wyniki pomiaru twardości na przekroju poprzecznym złączy przedstawiono na rys. 6 . Twardość materiału podstawowego wynosi ok. 270 290 HV1, co świadczy o dużej zawartości bainitu w stali i silnym umocnieniu wydzieleniowym ferrytu przez dyspersyjne wydzielenia węglikoazotków. Istotny jest także efekt umocnienia odkształceniowego stali podczas walcowania poniżej temperatury rekrystalizacji fazy $y$, o czym świadczy wyraźne ukierunkowanie struktury wyjściowej (rys. 4).

Przeprowadzone pomiary twardości na przekroju poprzecznym złączy spawanych przy różnych parametrach procesu wykazały, że w każdym z badanych złączy zaszły przemiany fazowe powodujące znaczny 
wzrost twardości stali, zarówno w przypadku spoiny jak i strefy wpływu ciepła. Wzrost twardości spoiny potwierdzają wyniki badań metalograficznych mikroskopowych, wykazujących obecność w spoinie struktury martenzytycznej w niemal całej objętości metalu spoiny (rys. 5). Największą twardość w zakresie między 370 a 400 HV1 wykazuje strefa przetopiona, bez wyraźnej zależności od zastosowanej energii liniowej w zakresie od 0,037 do 0,06 kJ/mm.

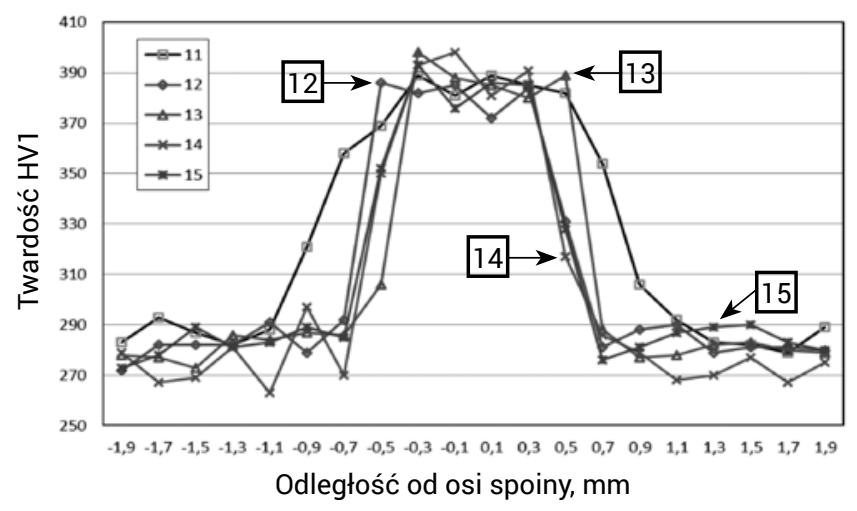

Rys. 6. Wyniki pomiaru twardości na przekroju poprzecznym złączy spawanych przy różnych parametrach procesu

Fig. 6. Results of hardness measurements along the cross section of the joint welded at different parameters of the process

Specyfika spawania laserowego charakteryzującego się dużą gęstością mocy wiązki laserowej i dużą prędkością spawania (bardzo duża szybkość chłodzenia) spowodowała występowanie przemiany martenzytycznej w całej objętości materiału. Przyczyną relatywnie niskiej twardości martenzytu stali CPW 800 jest ograniczona w niej do 0,08\% zawartość węgla, a stąd małe przesycenie martenzytu węglem. Uzyskana twardość mieści się w zakresie pomiędzy war- tościami uzyskiwanymi dla stali DP $[5,13 \div 15]$ i TRIP

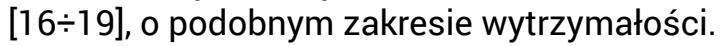

W przypadku spoiny wykonanej z największą energią liniową $(0,06 \mathrm{~kJ} / \mathrm{mm})$ można zaobserwować wyraźne poszerzenie strefy o dużej twardości, co odpowiada makrostrukturze stali ujawniającej najszerszą strefę przetopioną i SWC (rys. 3e). Spadek twardości w przypadku tego złącza jest najbardziej łagodny, podczas gdy w pozostałych przypadkach relatywnie stromy, co odpowiada wąskiej strefie przejściowej dla złączy spawanych w zakresie energii liniowej od 0,037 do $0,05 \mathrm{~kJ} / \mathrm{mm}$.

\section{Wytrzymałość na rozciąganie i próba zginania połączeń spawanych}

Badania wytrzymałości na rozciąganie prowadzono na maszynie wytrzymałościowej firmy Instron (model 4210). Próbki do badań przygotowano zgodnie $z$ wymaganiami PN-EN ISO 4163:2013, a do próby zginania zgodnie z PN-EN ISO 5173:2010. Dla każdego złącza przeprowadzono po pięć prób rozciągania oraz cztery próby zginania, po dwie z rozciąganiem lica i grani spoiny. Próbę zginania prowadzono $z$ użyciem trzpienia gnącego o średnicy $d=10 \mathrm{~mm}$. Próbki zginano do kąta $180^{\circ}$. W każdym przypadku w próbie rozciągania zerwanie próbki nastąpiło w znacznej (tj. ok. $20 \div 30 \mathrm{~mm}$ ) odległości od spoiny a wytrzymałość materiału podstawowego wynosita od 825 do $890 \mathrm{MPa}$. Wyniki wytrzymałości na rozciąganie przedstawiono w tablicy III. Podczas próby zginania nie zaobserwowano żadnych pęknięć ani rys złączy spawanych.

Tablica III. Wytrzymałość na rozciąganie połączeń spawanych laserowo blach ze stali CPW 800

Table III. Results of tensile strength test of laser welded joint of CPW 800 steel

\begin{tabular}{|c|l|c|c|}
\hline Numer próbki (moc wiązki) & Wyniki prób rozciągania, MPa & $\begin{array}{c}\text { Wartość średnia z prób } \\
\text { rozciągania, MPa }\end{array}$ & $\begin{array}{c}\text { Odchylenie } \\
\text { standardowe, MPa }\end{array}$ \\
\hline $11(0,060 \mathrm{~kJ} / \mathrm{mm})$ & 856,$4 ; 860,3 ; 863,9 ; 856,1 ; 847,2$ & 856,8 & 6,2 \\
\hline $12(0,050 \mathrm{~kJ} / \mathrm{mm})$ & 825,$6 ; 830,5 ; 825,1 ; 890,5 ; 825,9$ & 839,5 & 28,6 \\
\hline $13(0,048 \mathrm{~kJ} / \mathrm{mm})$ & 837,$1 ; 872,7 ; 832,8 ; 837,6 ; 862,1$ & 848,5 & 3,9 \\
\hline $14(0,040 \mathrm{~kJ} / \mathrm{mm})$ & 869,$2 ; 862,0 ; 864,6 ; 871,2 ; 863,9$ & 866,2 & 16,4 \\
\hline $15(0,037 \mathrm{~kJ} / \mathrm{mm})$ & 847,$2 ; 858,7 ; 872,1 ; 829,0 ; 842,4$ & 849,9 & \\
\hline
\end{tabular}




\section{Wnioski}

Przeprowadzone próby spawania laserowego potwierdziły możliwość uzyskania wysokiej jakości złączy spawanych ze stali typu Complex Phase w szerokim zakresie parametrów spawania. Mimo zastosowania atmosfery powietrza cykl spawalniczy charakteryzował się dużą stabilnością i przetopieniami pozbawionymi porowatości, podtopień i nadmiernego odparowania metalu. Wykonane próby wykazały, że energia liniowa spawania powinna być ograniczona do około $0,05 \mathrm{~kJ} / \mathrm{mm}$. Powyżej tej wartości uzyskuje się złącza o nadmiernej szerokości spoiny i strefy wpływu ciepła. Dynamiczny cykl spawania laserowego skutkuje otrzymaniem martenzytu w przeważającej części złącza. Ograniczone stężenie węgla w stali decyduje jednak, że jest to martenzyt niskowęglowy o relatywnie małym stopniu przesycenia węglem i wykazujący zadowalającą w aspekcie spawania twardość okoto 390 HV1. Duży udział bainitu w stali CPW 800 powoduje, że twardość materiału rodzimego jest jedynie około $25-30 \%$ niższa od twardości spoiny, co gwarantuje relatywnie dużą jednorodność własności wykonanych złączy. Wytrzymałość na rozciąganie połączeń spawanych była niemniejsza od $825 \mathrm{MPa}$, przy czym w każdym przypadku zerwanie rozciąganej próbki występowało poza spoiną.

\section{Literatura}

[1] Adamczyk J., Grajcar A.: Blachy samochodowe typu DP i TRIP walcowane metodą obróbki cieplno-mechanicznej. Hutnik - Wiadomości Hutnicze nr 7-8/2004, s. 305-309.

[2] Senkara J.: Współczesne stale karoseryjne dla przemysłu motoryzacyjnego i wytyczne technologiczne ich zgrzewania. Przegląd Spawalnictwa nr 11/2009, s. 3-7.

[3] Krajewski S., Nowacki J.: Mikrostruktura i właściwości stali o wysokiej wytrzymałości AHSS. Przegląd Spawalnictwa nr 7/2011, s. 22-27.

[4] Kowielski S., Mikno Z., Pietras A.: Welding of advanced highstrength steels. Biuletyn Instytutu Spawalnictwa nr 2/2012 s. 5-14.

[5] Rutkowski D., Ambroziak A.: Wpływ umocnienia laserowego współczesnych stali karoseryjnych dla przemysłu motoryzacyjnego na właściwości mechaniczne. Biuletyn Instytutu Spawalnictwa nr 5/2014, s. 50-58.

[6] Stano S.: Spawanie laserowe blach o zróżnicowanej grubości przeznaczonych na półfabrykaty karoserii samochodowych typu tailored blanks. Prace prowadzone w Instytucie Spawalnictwa. Biuletyn Instytutu Spawalnictwa nr 2/2005, s. 24-28.

[7] Grajcar A., Różański M.: Spawalność wysokowytrzymałych stali wielofazowych AHSS. Przegląd Spawalnictwa, nr 3/2014, s. 22-31.

[8] Gipiela M.L., Nikhare C., Marcondes P.V.P.: Experimental and numerical investigation of hole expansion on CPW800 steel. AIP Conf. Proc. 1567, Numisheet'2014, 2013, s. 406-409.

[9] Grajcar A.: Struktura stali C-Mn-Si-Al kształtowana z udziatem przemiany martenzytycznej indukowanej odkształceniem plastycznym. Wydawnictwo Politechniki Śląskiej, Gliwice 2009.

[10] Papkala H.: Zgrzewanie oporowe metali. Wydawnictwo KaBe, Krosno 2003.

[11] Gould J.E., Khurana S.P., Li T.: Predictions of microstructures when welding automotive advanced high-strength steels. Welding Journal nr 5/2006, s. 111-116.

[12] Klimpel A.: Technologie laserowe w spawalnictwie. Wydawnictwo Politechniki Śląskiej, Gliwice 2011.

[13] Poggio S., Ponte M., Gambaro C., Adamowski J.: Badanie zgrzewalności oporowej stali AHSS DP600. Przegląd Spawalnictwa nr 12/2005, s. 22-25.
[14] Zadroga L., Pietras A., Wegglowska A.: Zgrzewanie rezystancyjne punktowe blach typu DP450 i DP600. Biuletyn Instytutu Spawalnictwa nr 3/2007, s. 49-55.

[15] Węglowski M.S., Stano S., Osuch W., Michta G.: Laser welding of DP steel - characterization of microstructure of steel and welded joint. Inżynieria Materiałowa $\mathrm{nr} 3 / 2010$, s. 256-259.

[16] Grajcar A., Różański M., Stano S., Kowalski A., Grzegorczyk B.: Effect of heat input on microstructure and hardness distribution of laser welded Si-Al TRIP-type steel. Advances in Materials Science and Engineering, vol. 2014, 2014, doi. org/10.1155/2014/658947.

[17] Grajcar A., Różański M., Stano S., Kowalski A.: Microstructure characterization of laser-welded $\mathrm{Nb}$-microalloyed silicon-aluminum TRIP steel. Journal of Materials Engineering and Performance, vol. 23, 2014, s. 3400-3406.

[18] Cretteur L., Koruk A.I., Tosal-Martinez L.: Improvement of weldability of TRIP steels by use of in-situ pre- and postheat treatments. Steel Research, vol. 73, 2002, s. 314-319.

[19] Amirthalingam M., Hermans M.J.M., Richardson I.M.: Microstructural development during welding of silicon and aluminum based transformation induced plasticity steels - inclusion and elemental partitioning analysis. Metallurgical and Materials Transactions A, vol. 40A, 2009, s. 901-909.

[20] Grajcar A., Różański M., Kamińska M., Grzegorczyk B.: Study on non-metallic inclusions in laser-welded TRIP-aided $\mathrm{Nb}$-microalloyed steel. Archives of Metallurgy and Materials, vol. 59, 2014, s. 1163-1169.

[21] Lisiecki A., Mańka J.: Spawanie blach ze stali S420MC o podwyższonej granicy plastyczności laserem diodowym dużej mocy. Biuletyn Instytutu Spawalnictwa nr 3/2012, s. 67-71.

[22] Gruszczyk A., Griner S.: Własności połączeń spawanych i zgrzewanych stali obrobionych termomechanicznie. Przegląd Spawalnictwa nr 5-6/2006, s. 39-41.

[23] Górka J.: Własności i struktura złączy spawanych stali obrabianej termomechanicznie o wysokiej granicy plastyczności. Wydawnictwo Politechniki Śląskiej, Gliwice 2013.

[24] Mroczka K., Zielińska-Lipiec A., Ratuszek W., Tasak E.: Identyfikacja składników strukturalnych w strefie wpływu ciepła w stalach o dużej wytrzymałości. Hutnik - Wiadomości Hutnicze $\mathrm{nr}$ 7-8/2004, s. 396-399. 